\title{
PERTUMBUHAN DAN PRODUKSI TOMAT CHERRY (Lycopersicon esculentum Miller.) PADA KONSENTRASI NUTRISI YANG BERBEDA DENGAN SISTEM HIDROPONIK
}

\author{
Grecya Manalu \\ Program Studi Agroteknologi \\ Fakultas Pertanian, Universitas Sumatera Utara, Medan 20155, Indonesia \\ grecyamanalu87@gmail.com
}

\begin{abstract}
Increased growth and production of cherry tomato, especially in the lowlands is influenced by the availability of water, humidity, and cultivation technology of plants, so it takes hydroponic system to realize the growth and production enhancement of cherry tomato. This research aims to identify the proper concentration of nutrient on the growth and production of cherry tomato with hydroponic system. This research was conducted at Screenhouse of Royal Sumatera Housing, Medan Tuntungan ( \pm 32 meters above sea level), from March to August 2017. The research used Completely Randomized Design with one treatment factor that is nutrition concentration (1300 ppm,1750 ppm, and $2200 \mathrm{ppm})$. The results showed that the nutrient concentration of $1750 \mathrm{ppm}$ increase the growth of stem diameter. Nutrient concentration of 2200 ppm increases plant height, the speed of flowering, number of branches, number of segments, fruit weight, and number of fruits.
\end{abstract}

\begin{abstract}
Abstrak
Peningkatan pertumbuhan dan produksi tomat cherry khususnya di dataran rendah dipengaruhi oleh ketersediaan air, kelembaban, serta teknologi budidaya tanaman, sehingga diperlukan sistem hidroponik untuk mewujudkan peningkatan pertumbuhan dan produksi tomat cherry. Penelitian ini bertujuan untuk mengidentifikasi konsentrasi nutrisi yang tepat pada pertumbuhan dan produksi tomat cherry dengan sistem hidroponik. Penelitian ini dilaksanakan di Screenhouse Perumahan Royal Sumatera, Medan Tuntungan ( $\pm 32 \mathrm{~m} \mathrm{dpl}$ ), pada bulan Maret sampai dengan Agustus 2017. Penelitian menggunakan Rancangan Acak Lengkap dengan satu faktor perlakuan yaitu konsentrasi nutrisi (1300 ppm, 1750 ppm, dan 2200 ppm). Hasil penelitian menunjukkan bahwa konsentrasi nutrisi 1750 ppm meningkatkan pertumbuhan diameter batang. Konsentrasi nutrisi 2200 ppm meningkatkan tinggi tanaman, kecepatan umur berbunga, jumlah cabang, jumlah ruas, bobot buah, dan jumlah buah.
\end{abstract}

Kata kunci : tomat cherry, konsentrasi nutrisi dan hidroponik

\section{Pendahuluan}

Tomat cherry merupakan tanaman hortikultura yang populer di dunia. Tanaman ini bermanfaat bagi kesehatan karena mengandung vitamin A, B, C, karbohidrat, lemak, dan protein yang lebih tinggi dibanding tomat biasa. Tomat cherry juga merupakan varietas tomat yang bernilai ekonomi tinggi, harga jualnya mulai Rp. $20.000 / \mathrm{kg}$ - Rp. $30.000 / \mathrm{kg}$ bila dibandingkan dengan tomat jenis mutiara yang harga jualnya mulai Rp. 8.000/kg - Rp. 
12.000/kg. Kebutuhan akan tanaman ini mulai meningkat dan mulai banyak dikonsumsi segar sebagai buah meja maupun dalam bentuk olahan seperti tomat cherry kalengan, pasta, saus, ice cream, dan juice. Saat ini tomat cherry sering ditemukan di pasar modern seperti supermarket, hypermarket dan di restoran-restoran untuk masakan seperti salad, sedangkan tomat cherry di pasar tradisional masih sulit ditemukan, sehingga untuk memenuhi kebutuhan tomat cherry, Indonesia sering mengimport tomat cherry dari luar negeri. Selain itu, tomat cherry juga kurang banyak dibudidayakan karena pada umumnya tomat cherry dibudidayakan di dataran tinggi dan para peneliti tidak banyak yang tertarik untuk meneliti tanaman ini (Ali, 2013).

Permasalahan yang timbul pada budidaya tomat cherry dataran rendah terletak pada kurangnya kesuburan tanah, sumber air, dan kelembabannya, sehingga diperlukan pemberian air dan pupuk yang cukup (Kasiran, 2006). Untuk meningkatkan produksi tomat cherry di dataran rendah, diperlukan teknologi budidaya tanaman dengan sistem hidroponik irigasi tetes.

Pemanfaatan sistem hidroponik dalam budidaya tanaman, memungkinkan dilaksanakannya pemberian air dan pupuk secara bersamaan. Manajemen pemupukan (fertilization) dapat dilaksanakan secara terintegrasi dengan manajemen irigasi (irrigation) yang selanjutnya disebut fertigasi (fertilization and irrigation). Dalam sistem hidroponik, pengelolaan air dan hara difokuskan pada cara pemberian yang optimal sesuai dengan kebutuhan tanaman, umur tanaman dan kondisi lingkungan sehingga tercapai hasil yang maksimum (Susila, 2013).

Hidroponik irigasi tetes merupakan sistem hidroponik yang dikelompokkan pada hidroponik sistem terbuka. Hidroponik bag culture biasanya menggunakan sistem irigasi tetes yang merupakan cara hidroponik yang cocok untuk para pemula, sebab sistem ini tidak beresiko tinggi dalam budidaya tanaman (Susila, 2013). Keuntungan penerapan teknologi irigasi tetes, seperti halnya irigasi tetes Ro Drip merupakan salah satu cara penggunaan air yang efisien dan efektif, karena pemberian air dapat diatur secara tepat baik volume maupun sasarannya (Kasiran, 2006). Irigasi tetes juga dapat menekan serangan penyakit pada daun, karena air tidak diaplikasikan lewat daun sehingga dapat mempertahankan daun dalam kondisi kering yang berakibat dapat meningkatkan kerentanan tanaman terhadap serangan penyakit, dan dapat menekan penggunaan fungisida (Suarni, 2006). Meskipun memerlukan biaya awal yang relatif mahal untuk menerapkan sistem pengairan ini, tetapi penggunaan air, pupuk dan tenaga kerja pengontrol pengairan atau pemupukan tanaman dapat dihemat (Susila dan Roedhy, 2013).

Peningkatan jumlah unsur hara berbanding lurus dengan tingkat pertumbuhan tanaman. Hal ini membuat EC larutan hara perlu ditingkatkan sesuai dengan fase tumbuh tanaman. Pada umumnya, nilai EC pada stadia vegetatif sebesar $2,5 \mathrm{mmhos}(1750 \mathrm{ppm})$ dan pada stadia generatif sebesar 3,0 mmhos (2100 ppm). Peningkatan EC ini juga berbanding lurus dengan konsentrasi garam terlarut, tetapi tidak merubah rasio unsur hara yang terkandung di dalamnya (Susila, 2013).

\section{Bahan dan Metode}

Penelitian ini dilakukan di Screenhouse Perumahan Royal Sumatera, Medan Tuntungan 
pada ketinggian \pm 32 meter di atas permukaan laut, dimulai pada bulan Maret sampai dengan Agustus 2017.

Bahan yang digunakan adalah benih tomat cherry varietas First Love F1, arang sekam, cocopeat, nutrisi $\mathrm{AB}$ mix, fungisida, dan air. Alat yang digunakan adalah tray semai, TDS dan EC meter, $\mathrm{pH}$ meter, gelas ukur, ember, stik, penggaris/meteran, jangka sorong, handsprayer, timbangan, timer, tangki air, perangkat pipa irigasi tetes, tangki air, selang air, dan polibag.

Penelitian ini menggunakan Rancangan Acak Lengkap (RAL) dengan satu faktor perlakuan. Hasil analisis sidik ragam perlakuan yang berpengaruh nyata pada olahan data akan dilanjutkan dengan Uji Jarak Berganda Duncan (DMRT) pada taraf 5\% (Steel and Torrie, 1995).

Parameter yang di amati antara lain : tinggi tanaman, diameter batang, umur berbunga tanaman, jumlah cabang pertanaman, jumlah ruas pertanaman, jumlah buah pertanaman dan bobot buah pertanaman.

\section{Hasil dan Pembahasan}

\section{Tinggi Tanaman}

Analisis sidik ragam menunjukkan bahwa konsentrasi nutrisi berpengaruh nyata terhadap tinggi anaman tomat cherry umur $12 \mathrm{MST}$.

Tabel 1. Tinggi tanaman tomat cherry umur 12 MST pada perlakuan konsentrasi nutrisi

\begin{tabular}{ccc}
\hline Pengamatan & Konsentrasi Nutrisi $(\mathrm{ppm})$ & Rataan \\
\hline \multirow{2}{*}{$12 \mathrm{MST}$} & $\mathrm{N}_{1}(1300)$ & $177,36 \mathrm{a}$ \\
& $\mathrm{N}_{2}(1750)$ & $190,88 \mathrm{ab}$ \\
& $\mathrm{N}_{3}(2200)$ & $224,65 \mathrm{~b}$ \\
\hline
\end{tabular}

Keterangan: Angka - angka yang diikuti oleh huruf yang berbeda pada kolom yang sama menunjukkan berbeda nyata pada Uji Jarak Berganda Duncan pada taraf 5\%.

Tinggi tanaman tomat cherry umur 12 MST pada perlakuan konsentrasi nutrisi (Tabel 1) hasil analisis sidik ragam menunjukkan bahwa konsentrasi nutrisi 2200 ppm (N3) menghasilkan tinggi tanaman yang lebih tinggi dibandingkan perlakuan lainnya. Hal ini terjadi karena tanaman tomat cherry merupakan tanaman indeterminate yang terus mengalami pertambahan tinggi tanaman walaupun telah memasuki masa generatif. Pada masa generatif, tanaman membutuhkan konsentrasi nutrisi yang lebih tinggi. Menurut Susila (2013), peningkatan jumlah unsur hara berbanding lurus dengan tingkat pertumbuhan tanaman. Hal ini juga sejalan dengan penelitian Afandi (2016) yang menghasilkan tinggi tanaman tomat cherry tertinggi terdapat pada konsentrasi nutrisi tertinggi yaitu $6 \mathrm{ml} / \mathrm{L}$.

\section{Diameter Batang}

Hasil analisis sidik ragam konsentrasi nutrisi pada pengamatan diameter batang tomat cherry umur 2-12 MST disajikan pada Lampiran 8-29. Pemberian konsentrasi nutrisi berpengaruh nyata terhadap diameter batang tomat cherry umur 7-8 MST, tetapi berpengaruh tidak nyata pada umur 2-6 MST dan 9-12 MST. 
Tabel 2. Diameter batang tomat cherry umur 2-12 MST pada perlakuan konsentrasi nutrisi

\begin{tabular}{|c|c|c|}
\hline Pengamatan & Konsentrasi Nutrisi (ppm) & Rataan \\
\hline \multirow{3}{*}{$2 \mathrm{MST}$} & $\mathrm{N}_{1}(1300)$ & 3,39 \\
\hline & $\mathrm{N}_{2}(1750)$ & 3,48 \\
\hline & $\mathrm{N}_{3}(2200)$ & 3,37 \\
\hline \multirow{3}{*}{$3 \mathrm{MST}$} & $\mathrm{N}_{1}(1300)$ & 3,70 \\
\hline & $\mathrm{N}_{2}(1750)$ & 3,86 \\
\hline & $\mathrm{N}_{3}(2200)$ & 3,68 \\
\hline \multirow{3}{*}{$4 \mathrm{MST}$} & $\mathrm{N}_{1}(1300)$ & 4,12 \\
\hline & $\mathrm{N}_{2}(1750)$ & 4,38 \\
\hline & $\mathrm{N}_{3}(2200)$ & 4,14 \\
\hline \multirow{3}{*}{$5 \mathrm{MST}$} & $\mathrm{N}_{1}(1300)$ & 4,68 \\
\hline & $\mathrm{N}_{2}(1750)$ & 5,12 \\
\hline & $\mathrm{N}_{3}(2200)$ & 4,96 \\
\hline \multirow{3}{*}{$6 \mathrm{MST}$} & $\mathrm{N}_{1}(1300)$ & 5,17 \\
\hline & $\mathrm{N}_{2}(1750)$ & 5,61 \\
\hline & $\mathrm{N}_{3}(2200)$ & 5,46 \\
\hline \multirow{3}{*}{$7 \mathrm{MST}$} & $\mathrm{N}_{1}(1300)$ & $5,68 \mathrm{a}$ \\
\hline & $\mathrm{N}_{2}(1750)$ & $6,35 b$ \\
\hline & $\mathrm{N}_{3}(2200)$ & $6,25 \mathrm{~b}$ \\
\hline \multirow{3}{*}{$8 \mathrm{MST}$} & $\mathrm{N}_{1}(1300)$ & $6,20 \mathrm{a}$ \\
\hline & $\mathrm{N}_{2}(1750)$ & $6,81 b$ \\
\hline & $\mathrm{N}_{3}(2200)$ & $6,80 \mathrm{~b}$ \\
\hline \multirow{3}{*}{$9 \mathrm{MST}$} & $\mathrm{N}_{1}(1300)$ & 7,23 \\
\hline & $\mathrm{N}_{2}(1750)$ & 7,40 \\
\hline & $\mathrm{N}_{3}(2200)$ & 7,22 \\
\hline \multirow{3}{*}{$10 \mathrm{MST}$} & $\mathrm{N}_{1}(1300)$ & 7,72 \\
\hline & $\mathrm{N}_{2}(1750)$ & 7,88 \\
\hline & $\mathrm{N}_{3}(2200)$ & 7,72 \\
\hline \multirow{3}{*}{$11 \mathrm{MST}$} & $\mathrm{N}_{1}(1300)$ & 7,79 \\
\hline & $\mathrm{N}_{2}(1750)$ & 8,26 \\
\hline & $\mathrm{N}_{3}(2200)$ & 8,08 \\
\hline \multirow{3}{*}{12 MST } & $\mathrm{N}_{1}(1300)$ & 7,81 \\
\hline & $\mathrm{N}_{2}(1750)$ & 9,29 \\
\hline & $\mathrm{N}_{3}(2200)$ & 9,24 \\
\hline
\end{tabular}

Keterangan :Angka - angka yang diikuti oleh huruf yang berbeda pada kolom yang sama dan pada minggu amatan yang sama menunjukkan berbeda nyata pada Uji Jarak Berganda Duncan pada taraf $5 \%$.

Hasil analisis sidik ragam konsentrasi nutrisi juga menunjukkan pengaruh nyata terhadap diameter batang tomat cherry umur 7-8 MST, tetapi berpengaruh tidak nyata pada umur 2-6 MST dan umur 9-12 MST (Tabel 2). Hal ini terjadi karena pada umur 2-6 MST dan umur 10-12 MST dosis pemberian nutrisi/ frekuensi penyiraman tidak sebanyak dosis pemberian nutrisi pada umur 7-8 MST untuk mendukung fase pertumbuhan tomat cherry. Pada dosis yang terlalu rendah, pengaruh larutan hara tidak nyata (Wijayani, 2000; Marschner, 1986). Pada umur 8-9 MST tanaman tomat cherry mengalami fase pembentukan buah, dan memperoleh dosis pemberian nutrisi yang sama. Akan tetapi, pemberian konsentrasi nutrisi pada umur 9 MST tidak berpengaruh nyata. Kondisi ini diduga karena pada umur 9 MST 
tanaman tomat cherry mulai mengalami fase pematangan buah. Sehingga dosis nutrisi yang diberikan pada tomat cherry umur 9 MST digunakan untuk mendukung pertumbuhan tanaman yang meliputi pertumbuhan vegetatif (diameter batang) karena tanaman tomat cherry merupakan tanaman indeterminate, fase pembentukan buah dan proses pematangan buah. Fase pematangan buah dimulai pada umur 10-12 MST.

\section{Umur Berbunga Tanaman}

Aplikasi konsentrasi nutrisi pada tanaman tomat cherry berpengaruh nyata terhadap umur berbunga tomat cherry umur 4 MST. Data pengamatan umur berbunga tomat cherry umur 4 MST.

$\begin{aligned} & \text { Tabel 3. Umur berbunga tomat cherry umur } 4 \text { MST pada perlakuan konsentrasi } \\
& \text { nutrisi }\end{aligned}$
\begin{tabular}{ccc} 
Pengamatan & Konsentrasi Nutrisi (ppm) & Rataan \\
\hline \multirow{3}{*}{4 MST } & $\mathrm{N}_{1}(1300)$ & $26,70 \mathrm{~b}$ \\
& $\mathrm{~N}_{2}(1750)$ & $26,35 \mathrm{ab}$ \\
& $\mathrm{N}_{3}(2200)$ & $25,60 \mathrm{a}$ \\
\hline
\end{tabular}

Keterangan: Angka - angka yang diikuti oleh huruf yang berbeda pada kolom yang sama menunjukkan berbeda nyata pada Uji Jarak Berganda Duncan pada taraf 5\%.

Dari hasil analisis sidik ragam dapat dilihat bahwa pemberian konsentrasi nutrisi 1300 ppm sampai $2200 \mathrm{ppm}$ pada tomat cherry memberi pengaruh nyata terhadap umur berbunga tomat cherry Konsentrasi nutrisi 2200 ppm (N3) menghasilkan umur tanaman lebih cepat berbunga dibanding dengan perlakuan lainnya. Hal ini diduga terjadi karena pemberian nutrisi dengan EC 3,0 mmhos (setara 2200 ppm) merupakan nilai konsentrasi nutrisi yang mendukung vase generatif pada tomat cherry.

\section{Jumlah Cabang per Tanaman}

Respons tanaman tomat cherry terhadap konsentrasi nutrisi pada pengamatan jumlah cabang per tanaman tomat cherry berpengaruh nyata pada umur $12 \mathrm{MST}$.

\begin{tabular}{|c|c|c|}
\hline Pengamatan & Konsentrasi Nutrisi (ppm) & Rataan \\
\hline \multirow{3}{*}{$12 \mathrm{MST}$} & $\mathrm{N}_{1}(1300)$ & $26,45 \mathrm{ab}$ \\
\hline & $\mathrm{N}_{2}(1750)$ & $23,55 \mathrm{a}$ \\
\hline & $\mathrm{N}_{3}(2200)$ & $27,50 \mathrm{~b}$ \\
\hline
\end{tabular}

Keterangan: Angka - angka yang diikuti oleh huruf yang berbeda pada kolom yang sama menunjukkan berbeda nyata pada Uji Jarak Berganda Duncan pada taraf $5 \%$.

Jumlah cabang per tanaman tomat cherry dengan pemberian konsentrasi nutrisi $2200 \mathrm{ppm}$

(N3) lebih banyak dibandingkan dengan pemberian konsentrasi nutrisi 1750 ppm (N2), 
sedangkan jumlah cabang per tanaman dengan pemberian konsentrasi nutrisi 1300 ppm (N1) berbeda tidak nyata.

\section{Jumlah Ruas per Tanaman}

Data pengamatan jumlah ruas per tanaman tomat cherry umur 12 MST dan sidik ragam menunjukkan bahwa konsentrasi nutrisi berpengaruh nyata terhadap jumlah ruas per tanaman tomat cherry umur 12 MST.

Tabel 5. Jumlah ruas per tanaman tomat cherry umur 12 MST pada perlakuan konsentrasi nutrisi

\begin{tabular}{ccc}
\hline Pengamatan & Konsentrasi Nutrisi $(\mathrm{ppm})$ & Rataan \\
\hline \multirow{2}{*}{12 MST } & $\mathrm{N}_{1}(1300)$ & $29,00 \mathrm{~b}$ \\
& $\mathrm{~N}_{2}(1750)$ & $25,55 \mathrm{a}$ \\
& $\mathrm{N}_{3}(2200)$ & $29,95 \mathrm{~b}$ \\
\hline
\end{tabular}

Keterangan: Angka - angka yang diikuti oleh huruf yang berbeda pada kolom yang sama menunjukkan berbeda nyata pada Uji Jarak Berganda Duncan pada taraf $5 \%$.

Pemberian konsentrasi nutrisi juga berpengaruh nyata terhadap jumlah cabang per tanaman dan jumlah ruas per tanaman umur 12 MST Konsentrasi nutrisi 2200 ppm (N3) menghasilkan jumlah cabang per tanaman dan jumlah ruas per tanaman terbanyak dibandingkan perlakuan lainnya. Hal ini terjadi karena umur 12 MST merupakan umur panen tanaman tomat cherry. Pada fase generatif diperlukan peningkatan konsentrasi nutrisi untuk mendukung pertumbuhan tanaman. Hal ini sejalan dengan pernyataan Susila (2013) yang menyatakan bahwa peningkatan larutan hara untuk pertumbuhan tanaman paprika dimulai dari EC 2,5 mmhos (setara $1750 \mathrm{ppm}$ ) pada stadia vegetatif menjadi EC 3,0 mmhos (setara $2200 \mathrm{ppm}$ ) pada fase generative.

\section{Jumlah Buah per Tanaman}

Perlakuan konsentrasi nutrisi pada tomat cherry berpengaruh tidak nyata terhadap jumlah buah per tanaman tomat cherry.

Tabel 6. Jumlah buah per tanaman tomat cherry umur 12 MST pada perlakuan konsentrasi nutrisi

\begin{tabular}{ccc}
\hline Pengamatan & Konsentrasi Nutrisi $(\mathrm{ppm})$ & Rataan \\
\hline \multirow{3}{*}{$12 \mathrm{MST}$} & $\mathrm{N}_{1}(1300)$ & 21,80 \\
& $\mathrm{~N}_{2}(1750)$ & 10,20 \\
& $\mathrm{~N}_{3}(2200)$ & 25,20 \\
\hline
\end{tabular}

Pemberian konsentrasi nutrisi 1300 ppm sampai 2200 ppm pada tomat cherry berpengaruh tidak nyata terhadap jumlah buah tomat cherry yang dipanen (Tabel 6). Pengaruh tidak nyata ini berkaitan dengan jumlah bunga yang terbentuk. Kondisi lingkungan di lapangan menjadi salah satu faktor yang mempengaruhi pembentukan bunga menjadi buah. Salah satu faktor yang mempengaruhinya adalah suhu. Suhu di dalam screenhouse yang diukur dengan 
menggunakan termometer mencapai $45^{\circ} \mathrm{C}$. Menurut Rubazky dan Yamaguchi (1999), suhu optimum untuk pertumbuhan dan pembungaan tomat adalah $250 \mathrm{C}-300 \mathrm{C}$ pada siang hari, antara 160C - 200C pada malam hari dan 180C dan 240C merupakan suhu terbaik untuk pembentukan buah. Selain itu, suhu merupakan salah satu penghambat dalam proses fisiologi untuk sistem produksi tanaman ketika suhu tanaman berada di luar suhu optimal terendah maupun tertinggi (De Bilderling, 1980).

\section{Bobot Buah Pertanaman}

Data pengamatan bobot buah per tanaman tomat cherry umur 12 MST dan sidik ragamnya dapat dilihat pada Lampiran 39-41 yang menunjukkan bahwa konsentrasi nutrisi berpengaruh tidak nyata terhadap bobot buah per tanaman tomat cherry.

Tabel 7. Bobot buah per tanaman tomat cherry umur 12 MST pada perlakuan konsentrasi nutrisi

\begin{tabular}{ccc}
\hline Pengamatan & Konsentrasi Nutrisi $(\mathrm{ppm})$ & Rataan \\
\hline \multirow{2}{*}{ 12 MST } & $\mathrm{N}_{1}(1300)$ & 77,72 \\
& $\mathrm{~N}_{2}(1750)$ & 42,54 \\
& $\mathrm{~N}_{3}(2200)$ & 99,27 \\
\hline
\end{tabular}

Pemberian konsentrasi nutrisi 1300 ppm sampai 2200 ppm pada tomat cherry hasil analisis sidik ragam juga menunjukkan pengaruh tidak nyata terhadap pengamatan bobot buah tomat cherry yang dipanen (Tabel 7). Hal ini berkaitan dengan jumlah buah yang terbentuk pada setiap tanaman. Semakin tinggi jumlah buah yang dipanen maka semakin tinggi bobot buah. Suhu di dalam screenhouse yang mencapai 450C memberi pengaruh negatif terhadap pertumbuhan dan perkembangan tomat cherry. Pengaruh negatif tersebut menyebabkan rendahnya perkembangan polen, berkurangnya proses penyerbukan, hancurnya sel embrio pada putik sehingga menurunkan pembentukan buah (Kuo, 1979).

\section{Simpulan}

Pemberian konsentrasi nutrisi 1750 ppm (N2) meningkatkan diameter batang tanaman umur 7-8 MST. 2. Pemberian konsentrasi nutrisi 2200 ppm (N3) meningkatkan tinggi tanaman, kecepatan umur berbunga, jumlah cabang per tanaman, jumlah ruas per tanaman, jumlah buah per tanaman, dan bobot buah per tanaman.

\section{Referensi}

Afandi, D. 2016. Pengaruh Konsentrasi Nutrisi dan Macam Media Substrat terhadap Pertumbuhan dan Produksi Tomat Cherry (Lycopersicon esculentum var cerasiforme) dengan Sistem Hidroponik. Skripsi. Fakultas Pertanian. Universitas Jember, Jember.

Ali, I. 2013. Budidaya Tomat Cherry Menjanjikan. http://peluang usaha kontan.co.id. Diakses pada tanggal 1 Maret 2017.

De Bilderling, N. 1980. Construction and maintenance cost of controlled environment facilities. J. Hort. Sci. 15(4): 479-485. 
Kuo, C. G. 1979. Tomato Fruit-Set At Hight Temperatures. P:94-104. In Robert Cowell (Eds). 1st International Symposium on Tropical Tomato. AVRDC Publication, Taiwan.

Rubatzky, V. E and M. Yamaguchi. 1999. World Vegetables Principles, Production and Nutrition Values, 2nd ed. Aspen Publisher, Inc. Gaithersburg, Maryland..

Susila, A. D. 2006. Fertigasi pada Budidaya Tanaman Sayuran di dalam Greenhouse. Makalah. Depertemen Agronomi dan Hortikulutura. Fakultas Pertanian. Institut Pertanian Bogor, Bogor.

. 2013. Sistem Hidroponik. bahan ajar mata kuliah dasar dasar hortikultura. Makalah. Departemen Agronomi dan Hortukultura. Fakultas Pertanian. Institut Pertanian Bogor, Bogor.

Susila, A. D dan Roedhy P. 2013. Irigasi dan Fertigasi. Bahan Ajar Mata Kuliah Dasar Dasar Hortikultura. Departemen Agronomi dan Hortukultura Fakultas Pertanian. Institut Pertanian Bogor, Bogor.

Wijayani, A. 2000. Budidaya paprika secara hiroponik : Pengaruhnya terhadap serapan nitrogen dalam buah. Agrivet Vol 4, Juli 2000. Hlm. 60-65. Diakses pada tanggal 4 September 2017. 